\title{
NOTES AND TOPICS
}

\section{How Different Is The New South Africa?}

\section{Brian Dollery}

$\mathrm{V}$

ISITORS to apartheid South Africa who had followed Western media accounts of oppressive conditions in that country were invariably surprised at the goodwill characterising everyday relations among South Africans of all colours. More recent travellers to post-apartheid South Africa, conditioned by media reports of the benevolence of the Mandela administration, have been delighted but unsurprised by inter-racial harmony in the new South Africa. At first glance, this may appear to confirm that 'the more things change the more they stay the same'. But, on closer reflection, it becomes a useful metaphorical prism through which to examine the passage of events in contemporary South Africa.

It is widely believed that the poor performance of the South African economy since the early 1970 s, exacerbated from the mid-1980s by economic sanctions, played the decisive role in the demise of the old apartheid regime, unquestionably undefeated militarily. This view ignores less tangible evidence on the failure of the 1986 State of Emergency to suppress an urban black revolt, the exhaustion of a government which had been in power since 1948, and the political window of opportunity opened up by the collapse of the Soviet Union, and exaggerates the impact of trade and financial sanctions on the South African economy. But it cannot be disputed that economic growth rates in South Africa had been low and falling for two decades. Just as the poor performance of the South African economy in the 1980s weakened the Botha and De Klerk administrations, so the success of the new democracy may depend crucially on whether the Government of National Unity (GNU) under President Nelson Mandela can deliver substantial increases in material well-being to its predominantly poor black constituency.

\section{South Africa's Enduring Economic Problems}

Table 1 paints a grim picture of the performance of the South African economy and underscores the enduring character of its problems. For example, annual growth in real GDP averaging only 0.9 per cent over the period 1984-95, together with South Africa's high population growth rate, meant a decline in real per capita GDP of almost 15 per cent. At least three factors compound the difficulties in-

Brian Dollery is Associate Professor of Economics at the University of New England. 
volved in increasing the rate of economic growth. First, although accurate official estimates do not exist, South Africa has experienced a wave of illegal immigration over the recent past believed to number in the millions. Moreover, migrant flows through South Africa's long and porous borders will very probably increase if economic growth expands economic opportunities for those within its borders. Second, external constraints on South Africa's economy ensure that any domestic economic growth causes a balance-of-payments crisis. Finally, unemployment remains a major problem. Barker (1992) has estimated that around 40 per cent of the labour force cannot obtain employment in the formal economy, half of whom may hold informal sector jobs. Even assuming an economic growth rate of 5 per cent a year, Fallon and de Silva (1994) have calculated that formal sector unemployment will be around 37 per cent by 1998-2001 and 26 per cent by 2002-5. It therefore seems likely that future growth rates will mirror those achieved prior to the political transfer of power, and have the same debilitating political implications.

\section{Table 1}

South Africa's economic performance, 1984-96

\begin{tabular}{|c|c|c|c|c|}
\hline $\begin{array}{l}\text { Calendar } \\
\text { year }\end{array}$ & $\begin{array}{l}\text { Real } \\
\text { GDP } \\
(R \text { million) }\end{array}$ & change & $\begin{array}{l}\text { Real GDP } \\
\text { per capita } \\
\text { (Rands) }\end{array}$ & $\%$ change \\
\hline 1984 & 257,292 & 5.1 & 7,987 & 2.5 \\
\hline 1985 & 254,175 & -1.2 & 7,700 & 3.6 \\
\hline 1986 & 254,221 & 0.0 & 7,517 & -2.4 \\
\hline 1987 & 259,561 & 2.1 & 7,495 & -0.3 \\
\hline 1988 & 270,463 & 4.2 & 7,631 & 1.8 \\
\hline 1989 & 276,940 & 2.4 & 7,633 & 0.0 \\
\hline 1990 & 276,060 & -0.3 & 7,434 & -2.6 \\
\hline 1991 & 273,249 & -1.0 & 7,192 & -3.3 \\
\hline 1992 & 267,257 & -2.2 & 6,879 & -4.4 \\
\hline 1993 & 270,181 & 1.1 & 6,803 & -1.1 \\
\hline 1994 & 276,464 & 2.3 & 6,813 & 0.1 \\
\hline 1995 & 285,587 & 3.3 & 6,827 & 0.2 \\
\hline 1996 & - & $3.2^{*}$ & - & - \\
\hline Average & & & & \\
\hline $1984-95$ & & 0.9 & & -1.5 \\
\hline
\end{tabular}

*Estimated.

Sources: South African Department of Finance, Budget Review, Pretoria, 1995; South African Reserve Bank Quarterly Bulletins, 1995 and 1996.

Just as low rates of economic growth appear to be a continuing feature of contemporary South African society, so too are the causes of this economic malaise, which transcends the colour and ideological composition of successive governments. Various diagnoses have been offered. For example, Mohr (1994) examines 
growth patterns in South Africa from 1975 and finds that changes in world economic growth, world trade, technological progress, gold production, import substitution, foreign capital flows, and labour all served to depress South African economic performance. Similarly, Fallon and de Silva (1994) identify five sources of the poor performance of the South African economy since 1965: the ratio of investment to GDP has steadily fallen from a peak of about 16 per cent in 1971-76; an increasing proportion of the capital stock has been invested in the relatively unproductive public sector; macroeconomic policy has encouraged capital-intensive production techniques, a trend which has been amplified by rising real wage rates for black labour; 'skill accumulation has been inadequate, and there has been a growing imbalance between the nation's stocks of physical and human capital' (Fallon \& de Silva, 1994:65); and the South African economy has exhibited a more pronounced business cycle, resulting in the periodic under-utilisation of productive resources. Noting that gold mining has experienced rising production costs, falling ore grades and a weak gold price, Nattrass (1995) observes that South Africa's annual gold production fell as a share of world output from 66.6 per cent in 1981 to only 32.8 per cent by 1993 , which meant a loss of some 166,000 jobs since 1987 , or around a third of total direct employment in the industry. Finally, Bethlehem (1994) has argued that 'socio-political turbulence' and falling economic growth have been strongly correlated in the post-war South African economy.

Both pre- and post-apartheid administrations have followed monetary and fiscal policies broadly consistent with macroeconomic stability, notwithstanding some deficit financing of public spending and a degree of currency volatility. However, it has long been recognised that the South African economy has severe structural problems which have to be addressed before economic growth can be increased. Eckert and van Niekerk (1993) note that the first official proposal aimed at comprehensive economic reform was the 1979 Economic Development Programme 1978-1987, later amended to form the 1991 Revised Long-Term Strategy. This document proposed to reduce the role of the public sector in the South African economy so as to 'afford the private sector more opportunity to conduct business on a profit basis. It is hoped that in the process the natural operation of market forces will bring about a healthy competitive economic structure that will, among other things, create more job opportunities' (Economic Advisory Council of the State President, 1991:12). Although the essence of this official policy stance was retained and set out in some detail in the 1993 Normative Economic Model, the impetus for economic reform under the previous minority National Party government had already evaporated. The historic announcement by the De Klerk administration on 2 February 1990 unbanning the African National Congress and other political organisations included a commitment to freeze any further economic restructuring initiatives.

\section{The Reconstruction and Development Program}

Like its predecessors, the new GNU has also been long on rhetoric and short on action. Indeed, it appears that the GNU is relying on its grandiose Reconstruction 
and Development Program (RDP) to somehow ameliorate the structural rigidities which inhibit economic growth in South Africa. The RDP is based on 'six principles' set out in a 1994 RDP White Paper. These broad guidelines are: specific RDP programs must be 'integrated and sustainable'; initiatives must be 'peopledriven and people-centred'; programs must 'promote peace and security for all'; RDP developments must foster 'nation-building'; initiatives must 'link reconstruction and development'; and finally, initiatives must 'democratize South African society'. Actual projects subsumed under the RDP have been launched. In his 'state of nation' address on 24 May 1994, President Mandela announced a series of key programs, or 'Presidential Lead Projects', to inaugurate the first year of the RDP. In total, some 21 projects had been initiated by early 1995 with an additional four programs launched at the end of the 1994-95 financial year.

Undoubtedly, there was a need for the RDP or some similar growth-orientated redistribution scheme to capture the imagination of the South African electorate, as much as to solve economic and social problems. But it is unlikely to remedy many of South Africa's structural problems. In these respects, it is just the most recent in a long line of extravagant politicised development plans. It is even not altogether dissimilar to its predecessor, the so-called program of separate development or grand apartheid, which was also designed to change the complexion of South African society. In any event, early indications are ominous. For instance, although R39 billion was touted as the total cost of the RDP during the election campaign prior to April 1994, it now appears that this figure may represent only annual expenditure on the RDP in its 1998 final year, with the cost of the entire program estimated at R135 billion (Nolan, 1995:163). Similarly, Simkins (1996:85) points to the inauspicious beginnings of the RDP:

What progress has been made? The RDP Monitor of August 1995 reported that more than R1.7 billion of the R2.5 billion allocated to the Reconstruction and Development Fund in 1994-95 had not been spent in that fiscal year, and estimated that at least 20 per cent of the 1995-96 allocation would not be spent. The major reason is lack of state capacity.

Moreover, Simkins argues that parliamentary appropriations will never be sufficient to fund the RDP adequately, and so alternative arrangements, like privatisation, will have to be employed. Some commentators are even less charitable about the prospects for the success of the RDP. For example, Nattrass has observed that the entire RDP is simply 'a costly and ultimately unnecessary piece of bureaucratic musical chairs' (Weekly Mail, 18 March, 1995). It would thus appear that, like its grand apartheid antecedent, the RDP may be fulfilling its political purposes rather more than its intended economic objectives.

\section{Social Instability}

Numerous other trends, already evident during the Botha administration in the mid-1980s, continue unabated in the New South Africa. The disruption of black 
primary and secondary school education in South Africa, which was initiated by the African National Congress/South African Communist Party (ANC/SACP) alliance in the 1980s under the slogan 'Liberation Before Education', persists despite personal pleas from President Mandela himself. Although the political focus of activist school pupils is much more difficult to identify nowadays, the tactics employed clearly derive from the earlier period and include arson, assaults on teachers and non-participating students, vandalism of school premises, a refusal to attend classes, and even the occasional necklacing of some 'enemy of the people', usually educational administrators. Failure rates remain catastrophically high and the quality of the majority of successful matriculation candidates, as measured against their coloured, Indian and white counterparts, is depressingly low. The so-called Lost Generation of millions of highly politicised but largely illiterate and innumerate black people who were part of the school system during the 'Liberation Before Education' campaign of the $1980 \mathrm{~s}$, and are now virtually unemployable, is thus continually being augmented by new generations of equally ill-equipped young people. Even those who somehow achieve university entrance qualifications generally perform so badly at tertiary institutions that almost all South African universities now spend millions of rands on 'academic support programs', a euphemism for remedial firstyear classes. Furthermore, political unrest, as before under apartheid, regularly occurs on university campuses. Thus, whilst Wits University experiences continuing racial tension and sporadic disruption, other institutions, like the Pretoria Technikon and the University of Durban-Westville, have had to call in riot police and close for extended periods.

A similar ANC/SACP initiative introduced during the State of Emergency has also survived the transition to a post-apartheid South Africa and indeed now thrives as never before. This usually takes the form of rent boycotts but often includes a refusal to pay for electricity, water and other household utilities. Originally developed by ANC/SACP activists as a means of demonstrating the 'ungovernability' of the townships, these populist boycotts have now spread to other ethnic urban communities, due apparently to the widespread belief that the GNU is unable to force people to pay. This belief has apparently been strengthened as an unintended consequence of the Mandela administration's 'Masakhane Campaign' which exhorts township residents to pay rent and service charges through moral suasion. The result has been the accrual of massive debts by local authorities all over South Africa: a situation which is clearly untenable in the long run.

Another continuing feature of the South African political landscape, which is much better known to Australian audiences, is the continued violence in Kwazulu/Natal. Originally caused by Chief Mangusotho Buthelezi's rift with the ANC in the late 1970 s and his development of the Inkatha Movement, political violence between the ANC and the subsequent Inkatha Freedom Party (IFP) intensified in the 1980 s resulting in thousands of deaths in the province. The killing fields of Kwazulu/Natal continued through the transition to non-racial government and indeed intensified under the GNU. Despite the repeated personal intervention 
of President Mandela, political violence persists in Kwazulu/Natal and some Transvaal townships.

\section{Crime and Corruption}

Many Australians are also aware of the massive crime wave engulfing South African society. Johannesburg is now reported as having the highest recorded homicide rates among all nations that keep reliable records and car-jacked South Africanmade Mercedes Benz and BMW automobiles are sold throughout the rest of Africa. What is less commonly understood is that the present crime wave is simply an intensified continuation of a process which began with the ANC/SACP campaign to make the townships 'ungovernable' in the early 1980s. The aim of the campaign was to delegitimise the formal judicial system and replace it with 'people's courts' so that townships would become 'liberated areas'. Together with the flood of Soviet small arms into South Africa as part of the wider 'armed struggle', this campaign sanctioned violence as a legitimate means of achieving political and other outcomes in the eyes of the Lost Generation, and criminal as well as political violence rose inexorably. When the ANC/SACP alliance proclaimed the end of the armed struggle in the early 1990s, it had already bequeathed to South Africa tens of thousands of alienated and unemployable youths accustomed to armed violence and imbued with the notion that they were morally entitled to 'redistribute' material wealth at the point of a gun. Once again, the steady upward trend in violent crime in South Africa passed through the transition to non-racial democracy unaffected.

Corruption remains a depressing thread running through the country's post1948 history. South Africans can readily cite examples of corruption in the apartheid era, ranging from clandestine purchasing of residential land reclassified under the Group Areas Act in the 1960s, to 'Muldergate' in the 1970s, where secret plans to buy inter alia the Washington Post with taxpayers' money led to the theft of tens of millions of rands. Indeed, a final desperate attempt by National Party politicians to squeeze the last corrupt drop of superannuation out of the old order at the constitutional talks in May 1996 seems to symbolise the moral degradation of the apartheid's ruling elite.

However, members of the new ruling elite in South Africa have proved astonishingly adroit at learning the ropes. Indeed, one of the very first acts of the new GNU was to more than double the salaries of parliamentarians. At the national level, corruption is now rampant. The Reverend Allan Bocsak; a leading ANC activist, was obliged to withdraw his candidature as ambassador to the UN after a scandal about his misuse of foreign donor money intended for charity. Former cabinet minister Bantu Holomisa has testified before the Truth Commission that the ANC had accepted money from gambling magnate Sol Kerzner to protect him from prosecution with the full knowledge of President Mandela, Deputy President Thabo Mbeki and Sports Minister Steve Tshwete (Makhanya, 1995:4). This has since been confirmed by President Mandela. Former cabinet minister Abe Williams was obliged to resign from the GNU after a police investigation of corruption in his ministry. At the provincial level, widespread corruption is also endemic. Ri- 
ani De Wet, North-West provincial Member of the Executive Council (MEC), was dismissed amidst corruption allegations. Similar fates have befallen Free State MEC Vax Mayekiso and Mpumalanga political adviser Eugene Nyati.

Corruption is also widespread among the new bureaucracy. For example, mounting anecdotal evidence appears to suggest that although extensive and longstanding tariffs apply to most imported goods coming into South African ports, corrupt customs officers often no longer impose these duties on billions of rands worth of goods (Old Mutual Economic Research Unit, 1996:5). Similarly, a commission led by Mr Justice White has found evidence of the illegal promotion of thousands of civil servants to inflate their salaries, including around 8,000 police.

The fact that political change in South Africa has not been matched by underlying socio-economic trends is hardly surprising. True, much desirable change has occurred. After all, the relatively non-violent demise of apartheid in South Africa remains one of the wonders of the late 20th century. But the Western media are once again systematically misrepresenting South African society by presenting a false juxtaposition of a mythical satanic old order against an angelic new age. Unfortunately, human nature seldom changes and utopia is not found this side of the grave.

\section{References}

Barker, F. (1992), The South African Labour Market, van Schaik, Pretoria.

Bethlehem, R. (1994), 'Reconstruction and Development in South Africa', South African Joumal of Economics 62(3): 280-303.

Eckert, J. \& L. van Niekerk (1993), "The Horns of a Dilemma: Economic Discipline and Economic Development in South Africa', Development Southern Africa 10(1): 3-22.

Economic Advisory Council of the State President (1991), Revised Long-Term Strategy, Government Printer, Pretoria.

Fallon, P. \& L. De Silva (1994), South Africa: Economic Performance and Policies, World Bank, Washington (Discussion Paper No. 7).

Makhanya, M. (1996), 'ANC Must Learn to Cope with Scandals', The Star and SA Times International (16 August).

Mohr, P. (1994), 'Restructuring the South African Economy: Some Perinent Issues', Studies in Economics and Econometrics 18(2): 41-54.

Nattrass, N. (1995), 'The Crisis in South African Goldmining', World Development 23(5): 857-68.

Nolan, B. (1995), 'Poverty, Inequality and Reconstruction in South Africa', Development Policy Review 13: 151-71.

Old Mutual Economic Research Unit (1996), Economic Monitor, 2nd Quarter, Old Mutual, Cape Town.

Simkins, C. (1996), 'The New South Africa: Problems of Reconstruction', Joumal of Democracy 7(1): 82-95.

The author would like to thank an anonymous referee for helpful comments on an earlier and longer version of the article. 